\title{
New Species of Lipinia (Squamata: Scincidae) from Borneo, Revealed by Molecular and Morphological Data
}

\author{
INDRANEIL DAS ${ }^{1,2}$ AND CHRISTOPHER C. AUSTIN ${ }^{3}$ \\ ${ }^{1}$ Institute of Biodiversity and Environmental Conservation, Universiti Malaysia Sarawak, 94300, Kota Samarahan, \\ Sarawak, Malaysia; E-mail: idas@ibec.unimas.my \\ ${ }^{3}$ Museum of Natural Science, Louisiana State University, 119 Foster Hall, Baton Rouge, Louisiana 70803, USA; \\ E-mail: ccaustin@lsu.edu
}

\begin{abstract}
Aвstract.-A new species of scincid lizard of the genus Lipinia is described from isolated localities in Borneo, from Sabah, Sarawak, and Kalimantan. The species was formerly allocated to Lipinia quadrivittata (Peters, 1867), a species known from the southern Philippines and Sulawesi in eastern Indonesia. The new species is compared with congeners from Borneo and other parts of Southeast Asia and the South Pacific and is diagnosable in showing the following combination of characters: small body size (SVL to $40.6 \mathrm{~mm}$ ); external ear opening absent; lower eyelid with a clear spectacle; midbody scale rows 20; longitudinal scale rows between parietals and base of tail 46-50; lamellae under toe IV 16-17; supralabials 6; infralabials 6-7; subcaudals 68-74; and dorsum tan brown with dark gray-brown stripes. Although morphologically similar to the arboreal L. quadrivittata, the new species from Borneo differs in coloration and its preference for terrestrial habitats. In addition, analysis of DNA sequence data from 293 base-pairs of the cytochrome $b$ gene for the new species and four congeners (Lipinia leptosoma, Lipinia pulchella, Lipinia noctua, and L. quadrivittata) demonstrates it is a separate lineage $(>15 \%$ sequence divergence from its sister taxa $L$. quadrivittata) with an independent evolutionary history.
\end{abstract}

The scincid genus Lipinia Gray, 1845, which was revived from the synonymy of Lygosoma Hardwicke and Gray, 1827 by Mittleman (1952), contains 26 nominal species ranging from the Andaman and Nicobar Islands of India, east to Thailand and Cambodia, the Malay Peninsula, Sumatra, Borneo, the Philippines, to New Guinea and the Republic of Belau (formerly, Palau; Brown and Alcala, 1980:80-107; Welch et al., 1990; Austin, 1995; Das and Greer, 2002). Members of the genus are characterized by the following suite of characters: small body size (SVL to $58 \mathrm{~mm}$ ); lower eyelid with a clear window (except in Lipinia leptosoma); auricular lobules absent; body scales smooth; longitudinal scale rows at midbody $\leq 28$; basal subdigital lamellae expanded (slightly in some taxa); postorbital absent; vomers fused; pterygoid teeth absent; dorsal color pattern typically comprising a pale (rarely dark) middorsal stripe at least anteriorly; visceral fat bodies absent (except in Lipinia noctua); brood size of two (exceptionally one, as in Lipinia rouxi) (Das and Greer, 2002). A biogeographic origin in the Philippines or Southeast Asia, rather than New Guinea, was suggested by Austin (1998).

A few species are taxonomically cryptic, here meaning a reproductively independent unit that is not morphologically discernable from some

\footnotetext{
${ }^{2}$ Corresponding Author.
}

other recognized species (see Toda et al., 2000; Ota et al., 2001). For instance, Greer and Mys (1987) revived L. rouxi (Hediger, 1934), from New Ireland Island, from the synonymy of $L$. noctua (Lesson, 1826). This species is diagnosed by the loss of the left oviduct. Four species of Lipinia have been reported from Borneo (Das, 2004). Lygosoma (Mocoa) nitens Peters (1871) was described from "Sarawak" (in East Malaysia), this taxon at present known with certainty only from Gunung Pueh and Gunung Matang, and allocated to the genus Scincella Mittleman, 1950, by Mittleman (1952) and to Sphenomorphus Fitzinger, 1843, by Bauer et al. (1995:64). Das and Greer (2002) allocated this nominal species to Lipinia. The second Bornean species was originally described as Lygosoma vittigerum Boulenger, 1894, from "Sereinu (Sipora), Mentawei Islands" (= Pulau Sipura, Mentawai Archipelago, off Sumatera, Indonesia), was reported from the Baram District, Miri Division, Sarawak by de Rooij (1915:232, based on BMNH 97.3.4.2), and was subsequently collected from various other localities on the island. The rarest Bornean species, Lygosoma (Liolepisma) miangense Werner, 1910, is known from the lost holotype collected from "Pulo Miang, Ostküste von Borneo" (= Pulau Miang, Kalimantan Timur, Indonesia). The fourth species was allocated to Lygosoma (Cophoscincus) quadrivittatum Peters, 1867 (type locality: Mindanao in the Philippines) by Brown and Alcala (1956). This 
latter species was also reported from Borneo (as Siaphos quadrivittatum) by Lloyd et al. (1968) and (as Lipinia quadrivittata) by Tan (1993). Brown and Alcala (1956), who examined the Bornean specimens available to them (FMNH 72448, from East Coast Residency, southeast end of Dewhurst Bay, Sabah, East Malaysia; and FMNH 63678 from Pulau Nunukan, Kalimantan Timur, Indonesia), allocated them to Lygosoma quadrivittatum, upon failing to find systematic characters to separate them from the nominate populations in the Philippines, although the population from Sulawesi, eastern Indonesia, was allocated to the subspecies infralineolatum.

During fieldwork in Pulau Manukan, a landbridge island off the north coast of Sabah, Borneo, four specimens of a Lipinia were collected. They differ in subtle aspects of color pattern and are genetically distinct from $L$. quadrivittata. These four specimens and preexisting Bornean specimens formerly allocated to L. quadrivittata form the type series of a new species described herein.

\section{Materials And Methods}

Part of the type series was collected from Pulau Manukan, an island off the north coast of Sabah, at approximately $1100-1130 \mathrm{~h}$, photographed in life, euthanased using pentobarbitol, fixed in buffered formalin approximately $6 \mathrm{~h}$ after collection, and subsequently washed in water and transferred to $70 \%$ ethanol about two weeks after collection. Geographical coordinates for the type locality were taken with a Garmin eTrek $^{\mathrm{TM}}$ Global Positioning System (datum: wgs84). The rest of the type series as well as comparative material were examined on visits to or as loans from museums (see Acknowledgments).

The following measurements were taken with Mitutoyo ${ }^{\mathrm{TM}}$ dial vernier callipers (to the nearest $0.1 \mathrm{~mm}$ ) approximately 24 months after collection in the case of the Pulau Manukan material, approximately 40 years later in the case of the paratype from Sarawak: snout-vent length (SVL); tibia length (TBL), distance between surface of knee to surface of heel, with the knee flexed; head length (HL), distance between angle of jaws and snout-tip; head width (HW), measured across retroarticular process of the mandible; head depth (HD), greatest transverse depth of head, taken posterior of the orbital region); eye diameter (ED), horizontal diameter of the eyes-measured across the anterior and posterior margins of the palpebral margin; interorbital distance (IO), smallest distance between upper eyelids; internarial distance (IN), distance between nostrils; eye to snout distance (E-S), distance between anteriormost point of eyes and tip of snout; eye to nostril distance $(\mathrm{E}-\mathrm{N})$, distance between anteriormost point of eyes and posterior-edge of nostrils; nostril to snout distance (N-S), distance between anteriormost point of nostril and tip of snout; axilla to groin distance $(A-G)$, distance between posterior edge of forelimb at its insertion to body to anterior edge of hind limb at its insertion to body; and body width (BW), greatest width of body. In addition, details of digit scalation were taken on the left limbs. Nomenclature of head scales follows Taylor (1935:71); that of dorsal striping follows Storr et al. (1999:277). Color notes on the holotype were taken from Fujichrome Velvia (50 ASA) $35 \mathrm{~mm}$ slide transparency film. Means are given $\pm 1 \mathrm{SE}$.

Comparative materials examined are listed in Appendix 1. Sources of additional data on character states and distribution of other species of Lipinia are from Alcala (1986), Boulenger (1887, 1894, 1912), Brown and Alcala (1980), Brown and Fehlmann (1958), Das (1997, 2002), Das and Greer (2003), de Rooij (1915), Günther (2000), Manthey and Grossmann (1997), Shea and Greer (2002), Smith (1930), and Zug (1991).

Museum abbreviations, where available (indicated with an asterisk), follow Leviton et al. (1985, 1988). These include: Natural History Museum, London, UK $\left(\mathrm{BMNH}^{*}\right)$; California Academy of Sciences, San Franciso (CAS*); Field Museum of Natural History, Chicago $\left(\mathrm{FMNH}^{*}\right)$; Museum of the Department of Biology, La Sierra University, Riverside (LSUHC); Museum of Comparative Zoology, Harvard University $\left(\mathrm{MCZ}^{*}\right)$; Sarawak Biodiversity Centre, Semenggoh, Sarawak, Kuching, Malaysia (SBC); Sarawak Museum, Kuching, Malaysia $\left(\mathrm{SM}^{*}\right)$; Sabah Parks Museum, Gunung Kinabalu National Park, Malaysia (SP); "Borneensis" Collection, Universiti Malaysia Sabah, Kota Kinabalu, Sabah, Malaysia (UMS); Raffles Museum of Biodiversity Research, National University of Singapore, Singapore (ZRC; the abbreviation used in Leviton et al., 1985, is

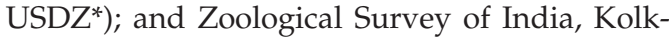
ata, India $\left(\mathrm{ZSI}^{*}\right)$.

Specimens and Tissues.-Muscle and liver tissue samples were dissected from freshly sacrificed specimens, and stored either at $-80^{\circ} \mathrm{C}$ or in $90 \%$ ethanol. DNA was isolated from either muscle or liver tissues following the protocols of Hillis et al. (1990). Appendix 2 provides DNA sequence data from the mitochondrial cytochrome $b$ (cytb) gene for the new species of Lipinia dealt with here (ZRC 2.57289), Lipinia quadrivittata (topotype material from Mindanao; second author's field number, CCA 1268-70), and three other species (L. noctua TNHC 51595 [Papua New Guinea], L. leptosoma 
SAMA R47903-4 [Palau], and L. pulchella TNHC 53979 [Philippines]).

DNA Isolation, Amplification, and Sequencing.Polymerase chain reaction (PCR) was used to amplify a 293 base-pair region of the cytb gene. The protocols of Hillis et al. (1990) were followed to amplify double-stranded PCR products. The specific thermal cycle used is as follows: (1) one cycle at $94^{\circ} \mathrm{C} \times 3 \mathrm{~min}, 47^{\circ} \mathrm{C} \times$ $1 \mathrm{~min}$, and $72^{\circ} \mathrm{C} \times 1$ minute; (2) 34 cycles at $94^{\circ} \mathrm{C} \times 45 \mathrm{sec}, 47^{\circ} \mathrm{C} \times 45 \mathrm{sec}$, and $72^{\circ} \mathrm{C} \times 1 \mathrm{~min}$; (3) one cycle at $72^{\circ} \mathrm{C} \times 6 \mathrm{~min}$. The primers used were L14841 5'AAA AAG CTT CCA TCC AAC ATC TCA GCA TGA TGA AA3' and H15149 5'AAA CTG CAG CCC CTC AGA ATG ATA TTT GTC CTC A3' (Kocher et al., 1989). Cytochrome $b$ was chosen because of its general utility for resolving divergences among Australasian skinks (Graybeal, 1994; Austin, 1999; Austin and Zug, 1999). PCR products were sequenced using ABI Big Dye version 3 terminator cycle sequencing kit and run on an $\mathrm{ABI}$ 3100 automated DNA sequencer.

Genetic Analysis.-To assess the genetic distinctiveness of the new species as an independent lineage, in particular compared to Lipinia quadrivittata with which it had long been confused, we performed genetic comparisons with other Lipinia for which we had tissue samples. Lipinia quadrivittata was hypothesized to be the sister taxa to the new Bornean species. Lipinia is presumed to be monophyletic and is a member of the Sphenomorphus-group of lygosomine skinks (Greer, 1974), and we chose the genus Sphenomorphus as an outgroup based on previous morphological and molecular work (Greer, 1974; Austin, 1995, 1998; CCA unpubl. data). We use both maximum likelihood (ML) and maximum parsimony (MP) methods to generate hypotheses of phylogenetic relationships.

DNA sequences were aligned using Clustal $X$ (Thompson et al., 1997). Maximum likelihood (ML) and maximum parsimony (MP) were the two optimality criteria used to assess phylogenetic relationships (Edwards, 1972; Felsenstein, 1981). All phylogenetic analysis were done using PAUP* 4 (Swofford, 1999). The presence of a bias in the type of base substitutions for DNA sequences has been well documented (Wakeley, 1994, 1996). To take into account transition/transvertion bias and among-site rate variation that can sometimes lead to an underestimation of the transition/transversion bias the GTR $+\mathrm{I}+\Gamma$ model of sequence evolution was chosen using Modeltest (Posada and Crandall, 1998). All searches were done using the heuristic search options in PAUP* with 20 random addition sequences, with initial trees obtained by stepwise addition, followed by branch swapping using the tree bisection-reconstruction (TBR) method implemented in PAUP*. In both MP and ML analyses, the branch-and-bound algorithm, which guarantees to find the optimal tree or trees, was used to search tree space. Tree reliability for both ML and MP criteria was evaluated by the nonparametric bootstrap resampling method (Felsenstein, 1985; Hillis and Bull, 1993).

\section{RESULTS}

Two hundred ninety three base-pairs from 10 individuals were aligned using Clustal $X$ (Thompson et al., 1997). Of these, 116 sites were variable, and 83 sites were parsimony-informative (GenBank accession numbers). No insertions or deletions (indels) were observed. An open reading frame for both genes was observed by alignments based on codon positions by translating DNA sequence into protein sequences using MacClade (version 4). Using the maximum likelihood GTR $+I+\Gamma$ model, among-site rate variation was incorporated. Maximum likelihood analyses resulted in a single optimal tree $(-\ln$ likelihood $=1260.669)$. Maximum parsimony analyses resulted in a single most parsimonious tree with the same topology as the ML optimal tree (tree length = 275 , consistency index $=0.77$, homoplasy index $=0.23$, rescaled consistency index $=0.58$; Fig. 1). Bootstrap proportions are for 100 and 500 pseudoreplicates, for ML and MP, respectively. The matrix for both uncorrected pairwise genetic distances are presented in Table 1.

All nodes on the tree are well supported $(\geq 70)$. Phylogenetic results suggest that the new species from Borneo being described here and L. quadrivittata are sister taxa. Genetic distances between the two species are substantial (15-16\%; Table 1) and correspond to typical levels of species level differentiation in lizards (Thorpe et al., 1994; Gonzalez et al., 1996; Thorpe, 1996; Thorpe and Malhotra, 1998).

\section{SYSTEMATICS}

Lipinia inexpectata sp. nov.

Figures 2-3

Lygosoma quadrivittatum: de Rooij, 1915. Reptiles Indo-Australian Arch. 1:271 (in part).

?Lygosoma quadrivittatum: Smedley, 1928. Malayan Br. Roy. Asiatic Soc. 6(3):77. (non-Lygosoma [Cophoscincus] quadrivittatum Peters, 1867).

Lygosoma quadrivitatum: Brown and Alcala, 1956. Occ. Pap. nat. Hist. Mus. Stanford University (3):3 (in part).

?Saiphos quadrivittatum: Taylor, 1963. University of Kansas Sci. Bull. 44:1053. 


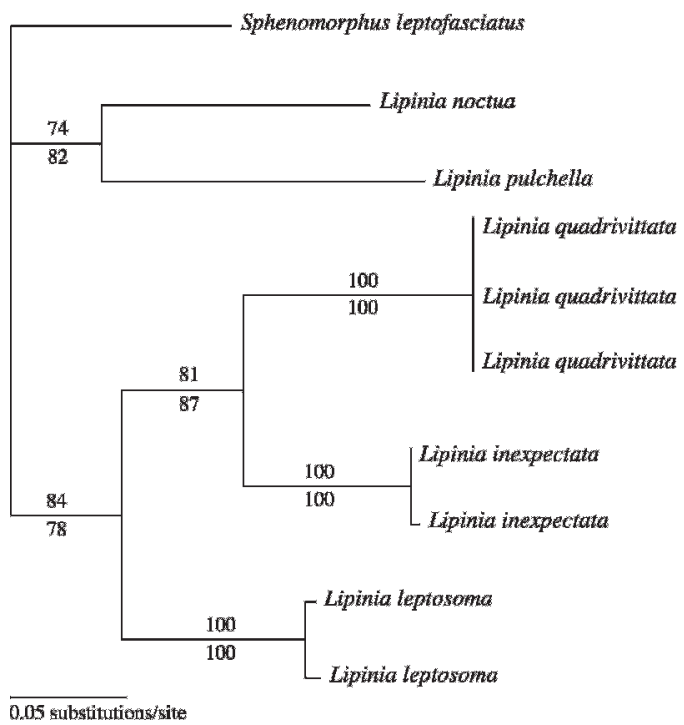

FIG. 1. Phylogram of the maximum likelihood tree obtained from PAUP* searches using Sphenomorphus leptofasciatus sequences as an outgroup. Maximum parsimony searches resulted is a single tree with the same topology as the ML tree. Support for inferred clades is assessed by nonparametric bootstrap values for $100 \mathrm{ML}$ and $500 \mathrm{MP}$ pseudoreplicates, above and below each branch, respectively.

Siaphos quadrivittatum: Lloyd, Inger, and King, 1968. American Natural. 202(928):499 (non-Lygosoma [Cophoscincus] quadrivittatum Peters, 1867).

Lipinia quadrivittata: Tan, 1993. Checklist Lizards Sabah:6. (non-Lygosoma [Cophoscincus] quadrivittatum Peters, 1867).

Lipinia quadrivittata: Iskandar, 2004. Amphibians and Reptiles Malinau Region:14;20 (nonLygosoma [Cophoscincus] quadrivittatum Peters, 1867).

Lipinia undescribed species: Das, 2004. Lizards of Borneo:6;60.

Lipinia quadrivittata: Hikida and Ota, 2005. Curr. Herpetol. 24(1):46. (non-Lygosoma [Cophoscincus] quadrivittatum Peters, 1867).
Holotype.-ZRC 2.5728 (field number ID7191; holotype) from Pulau Manukan $\left(05^{\circ} 58^{\prime} \mathrm{N}\right.$; $115^{\circ} 59^{\prime}$ E), Kota Kinabalu District, Sabah, East Malaysia, C. C. Austin and I. Das, collectors, 5 December 2000. Adult female (with paired shelled ova in the oviducts).

Paratypes.-ZRC 2.5729-30 (field numbers ID-7192-93), SP uncataloged (field number ID-7190), three paratopotypes, other data as for holotype; FMNH 138538, Nanga Tekalit Camp on Sungei Mengiong $\left(01^{\circ} 37^{\prime} \mathrm{N}\right.$ $\left.113^{\circ} 38^{\prime} \mathrm{E}\right)$, Kapit Division, Sarawak, East Malaysia, R. F. Inger, B. Greenberg, and F. W. King, collectors, 16 September 1962.

Diagnosis.-A small (SVL to $40.6 \mathrm{~mm}$ ) species of Lipinia, diagnosable from congeneric species in having the following combination of characters: external ear opening absent; lower eyelid with a clear spectacle; 20 midbody scale rows; 46-50 longitudinal scale rows between parietals and base of tail; 16-17 lamellae under toe IV; 6 supralabials; 6-7 infralabials; $68-74$ subcaudals; dorsum tan brown with dark gray brown stripes; dorsum tan brown with a series of dark gray brown stripes; a series of dark spots arranged in a longitudinal series bilaterally on each outer side of the paravertebral stripes; labials unbarred; venter yellowish-cream with pale gray smudges, and a unique $c y t b$ gene sequence.

Description of Holotype.-Gravid female, SVL $40.0 \mathrm{~mm}$, TL $37.7 \mathrm{~mm}$; snout acute (IN:IO ratio 0.54 ), slightly projecting beyond lower jaws; nostril laterally oriented, oval, situated closer to snout-tip than to orbit (E-N:E-S ratio 0.72); head relatively long, slightly longer than wide, HL $5.1 \mathrm{~mm}$, HW $4.7 \mathrm{~mm}$ (HL:HW ratio 1.09), slightly flattened, HD $3.3 \mathrm{~mm}$ (HL:HD ratio 1.55); rostral broad, projecting only moderately onto snout; posterior border of rostral nearly straight; frontonasal trapezoid, wider than long; frontal elongated, arrow-shaped, wider anteriorly; frontoparietals fused; prefrontals small, widely separated; interparietal single, subequal

TABLE 1. Summary of the mean inferred uncorrected pairwise genetic distances for the mitochondrial $c y t b$ gene for Lipinia inexpectata and four congeners.

\begin{tabular}{|c|c|c|c|c|c|c|c|c|c|c|}
\hline & 1 & 2 & 3 & 4 & 5 & 6 & 7 & 8 & 9 & 10 \\
\hline 1 TNHC 51595 & - & & & & & & & & & \\
\hline 2 SAMR 4195 & 0.18771 & - & & & & & & & & \\
\hline 3 CCA1269 & 0.19113 & 0.19795 & - & & & & & & & \\
\hline 4 CCA1268 & 0.19454 & 0.20137 & 0.00341 & - & & & & & & \\
\hline 5 CCA1270 & 0.19113 & 0.19795 & 0.00000 & 0.00341 & - & & & & & \\
\hline 6 ID7190 & 0.23549 & 0.20478 & 0.15358 & 0.15700 & 0.15358 & 一 & & & & \\
\hline 7 ID7191 & 0.23891 & 0.20819 & 0.15700 & 0.16041 & 0.15700 & 0.00341 & 一 & & & \\
\hline 8 SAMA R47903 & 0.21502 & 0.18430 & 0.19113 & 0.19454 & 0.19113 & 0.16041 & 0.16382 & - & & \\
\hline 9 SAMA R47904 & 0.20819 & 0.17747 & 0.19454 & 0.19795 & 0.19454 & 0.16382 & 0.16724 & 0.01024 & - & \\
\hline 10 TNHC 53979 & 0.20819 & 0.20478 & 0.22184 & 0.22526 & 0.22184 & 0.23208 & 0.23549 & 0.20137 & 0.20819 & - \\
\hline
\end{tabular}




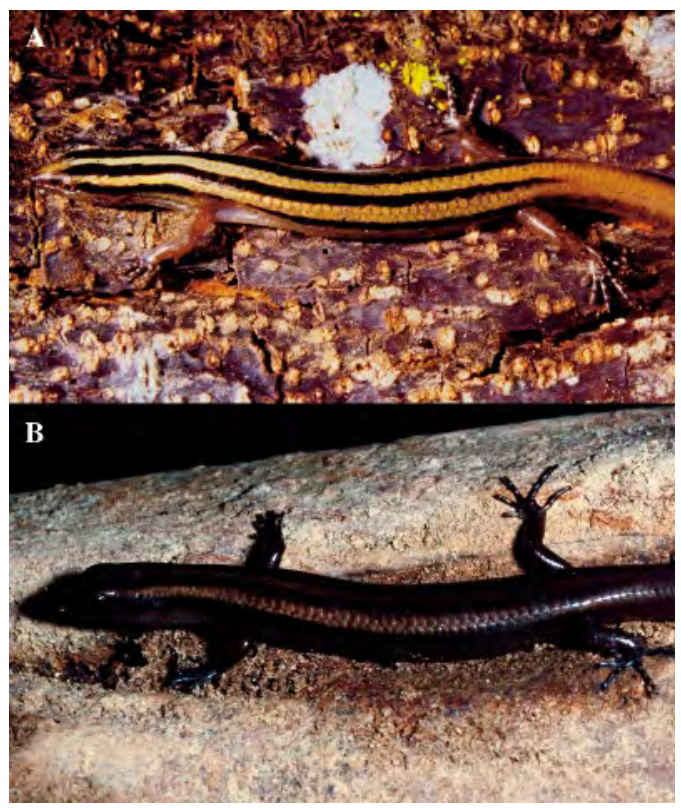

FIG. 2. Dorsolateral view of holotype of Lipinia inexpectata sp. nov. (ZRC 2.5728) in life compared with its sister taxa Lipinia quadrivittata. (A) Lipinia quadrivittata (CCA 1263) from southern Mindanao, Philippines. (B) Lipinia inexpectata (ZRC 2.5728).

to frontonasal; parietals in narrow contact posterior to interparietal; parietal eye spot situated at posterior half of interparietal; four supraoculars; three supraciliaries; nostrils located within nasals; postnasal absent; loreals squarish, two in number; equal in height; two presuboculars, separating supralabial III from orbit; six supralabials (supralabial IV contacting orbit of eye); three postsuboculars; three postoculars; two pretemporals; three temporals, the dorsal largest; two pairs of nuchals; seven infralabials; one scale separates second pair of enlarged chin shields; three scales separate third pair of chin shields; enlarged chin shields contact infralabials; external ear opening absent, its location indicated by a shallow depression; eyes relatively large; pupil rounded; lower eyelid with a clear window, approximately one-half eye diameter; scales on upper row of lower eyelid small, 10 in number; tongue short, undivided anteriorly, pointed; teeth small, somewhat obtuse.

Body slender, BW $7.8 \mathrm{~mm}$ (BW:SVL ratio $0.20)$; head slightly distinct from neck and from body; 48 longitudinal scale rows from parietal to above level of anterior margin of hind limb; 58 ventrals, counted from first postgular to last scale before preanals; body scales smooth, subcycloid; 20 transverse scale rows at midbody; 74 subcaudals; abdominal scales larger
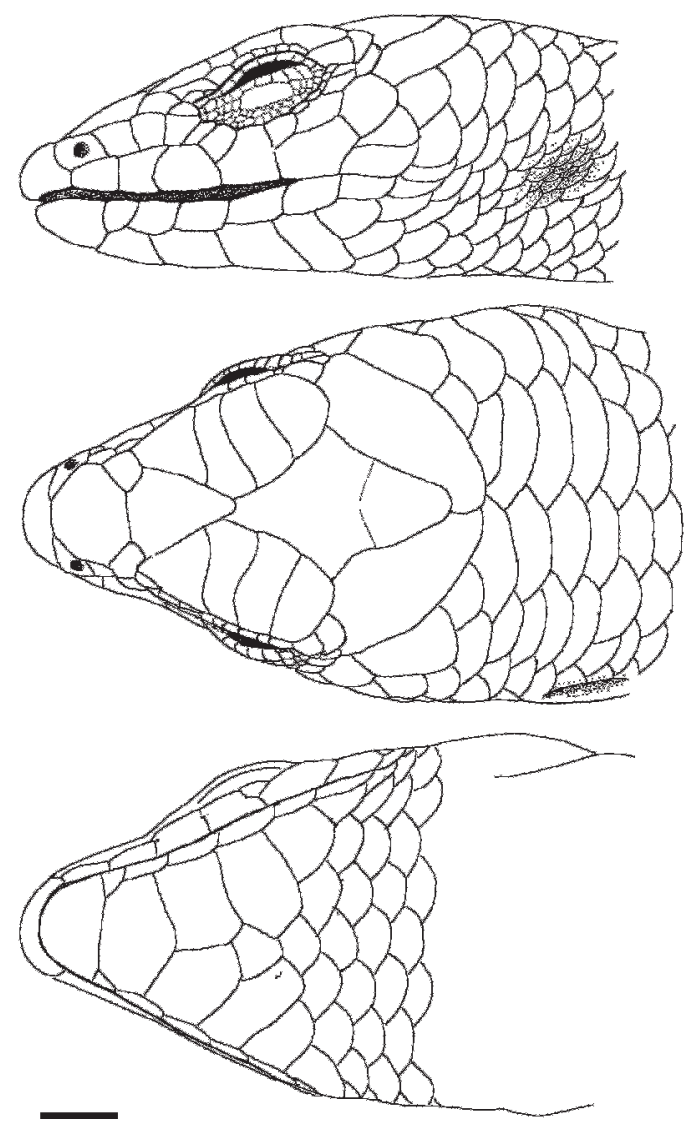

FIG. 3. Head scalation in the holotype of Lipinia inexpectata sp. nov. (ZRC 2.5728). (Top) Lateral view. (Middle) Dorsal view. (Bottom) Ventral view. Scale marker $=2 \mathrm{~mm}$.

than throat and pectoral scales, the median ventral scales also enlarged relative to scales on flanks; preanals enlarged, median pair of preanals overlap lateral preanals; tail relatively long (TL:SVL ratio 0.94), tip rounded, tail base not wider than rest of tail; tail gradually tapering to a point; median row of subcaudals slightly enlarged.

Limbs relatively short; pentadactyle and clawed; all lamellae smooth and enlarged; adpressed limbs failing to meet; lamellae under finger I-6; II-10; III-10; IV-12; V-9; lamellae under toes I-8; II-9; III-12; IV-13; V-10.

Coloration (in Preservative).-Dorsum tan brown (= pale) with a series of dark gray brown (= dark) stripes. A pale vertebral stripe extends from the interorbital region, across nape and midbody, to the tail, and down to the tip; on midbody, it is half a scale wide and lies on half of each of the two paravertebral scale series; the paired dark paravertebral stripes extend from the level of second supraocular, and 
extend to the tail tip; dark spots arranged in a longitudinal series bilaterally on each outer side of the paravertebral stripes; the paired pale dorsal stripes start from the level of the second supraoculars and terminate at the inguinal region; and finally, the paired dark laterodorsal stripes extend from postocular region to groin. All stripes are broadest at midbody and show reduced contrast towards posterior of body. Snout-tip dark gray; labials unbarred; tongue dark gray; venter yellowish-cream with pale gray smudges, forming a longitudinal stripe, especially along pectoral region; limbs unbanded; scales on undersurface of limbs light gray; manus and pres dark gray; undersurface of tail yellowish-cream.

Measurements (in Millimeters; Holotype with the Variation Shown in the Type Series in Parentheses).-SVL 40.0 (38.0-40.6, mean $39.00 \pm 0.54)$; HL 5.1 (4.7-5.1, mean $4.94 \pm 0.707)$; HW 4.7 (4.0-4.8, mean $4.58 \pm 0.15)$; HD 3.3 (3.1-3.3, mean $3.22 \pm 0.05)$; BW 7.8 (5.4-7.8, mean $6.30 \pm$ $0.41)$; TBL 4.3 (4.2-5.5, mean $4.46 \pm 0.28)$; ED 1.6 (1.2-1.6, mean $1.50 \pm 0.08)$; UE 1.9 (1.4-1.9, mean $1.52 \pm 0.10)$; IN 1.3 (1.1-1.3, mean $1.22 \pm$ $0.50) ; \mathrm{IO} 2.4$ (2.2-2.5, mean $2.38 \pm 0.05)$; E-S 2.5 (2.5-2.6, mean $2.52 \pm 0.02)$; E-N 1.8 (1.4-1.8, mean $1.54 \pm 0.07)$; N-S $1.0(0.6-1.0$, mean $0.76 \pm$ 0.07); A-G 23.6 (18.8-23.6, mean $21.74 \pm 0.86)$; TL 37.7 (35.7-46.2, mean $38.87 \pm 2.48$; TL of ZRC 2.5730 is a regenerated nubbin, $12.6 \mathrm{~mm}$ long and was not considered).

Variation (Holotype with the Variation Shown in the Type Series in Parentheses).--Transverse scale rows at midbody 20 (no variation); longitudinal scale rows 48 (46-50, mean $47.80 \pm 0.66)$; ventral scale rows 58 (49-58, mean $53.60 \pm 1.50)$; supralabials 6 (no variation); infralabials 7 (67 , mean $6.20 \pm 0.20)$; subcaudals 74 (68-74, mean $71.25 \pm 1.25$ ); lamellae under toe IV 17 (16-17, mean $16.40 \pm 0.25)$. Additional material of the new species examined are in Appendix 1. No variation in characters listed were observed between the populations on Pulau Manukan and those on Borneo.

Etymology.-The species name (an adjective in feminine form) refers to the unexpected nature of the discovery of the type series. This species was referred to Lipinia quadrivittata for 90 years since the work of de Rooij (1915).

Ecological Notes.-Part of the type series was collected from under two fallen tree trunks, approximately $10 \mathrm{~m}$ from the beach, at the edge of a disturbed primary forest. Two individuals were found under each log. Pulau Manukan is one of the more well-explored islands off the coast of Sabah, within the Tunku Abdul Rahman National Park (see Repin and Sundaling, 2000). Although a large number of congeners are arboreal (e.g., Lipinia leptosoma, L. pulchella,
L. quadrivittata, L. rouxi, L. semperi, L. subvittata, and L. vittigera; see Brown and Fehlmann, 1958; Brown and Alcala, 1980:89, 95-96; Greer and Mys, 1987), the new species being described here is terrestrial, a trait shared by a few congeneric species, such as L. macrotympanum, L. surda, and some populations of L. noctua (Greer and Mys, 1987; Das, 1998). The holotype is a female, containing one ova in each oviduct.

This landbridge island is underlaid by folded sandstone and sedimentary rocks, and was presumably detached from the Crocker Range of the Sabah mainland by a rise in sea level during the last Pleistocene post glaciation event (Voris, 2000). A number of vegetation types are represented, depending on local conditions. The coastal beach vegetation and mangroves are replaced in the interior by primary rain forests, comprising a rich dipterocarp flora. The adjacent primary forest is dominated by dipterocarps, including Dipterocarpus grandiflorus, Dipterocarpus acutangulus, as well as Shorea falciferoides, Shorea macroptera, Shorea laxa, Shorea angustiflorus, and Shorea confusca (floral inventory in Repin and Sundaling, 2000). The only other species of lizard found on Pulau Manukan was Hemidactylus frenatus Duméril and Bibron, 1836 (ZRC 2.5301). However, Nanga Tekalit in Sarawak, where the FMNH paratype of the new species of Lipinia was also collected, is a lowland dipterocarp forest, with a rich herpetofauna, including as many as 40 species of lizards (see Lloyd et al., 1968; Inger, 1980).

We are unclear of the systematic status of populations referred to Lipinia quadrivittata from southern Thailand (referred to as Saiphos quadrivittatum by Taylor, 1963:1053), the Malay Peninsula (Boulenger, 1912; Taylor, 1963; Denzer and Manthey, 1991), and from Pulau Siantan, in the Anambas Archipelago (referred to as Lygosoma quadrivittatum by Smedley, 1928), because no specimens from these localities could be examined.

Comparisons.-The new species of Lipinia from Borneo is most similar in gross morphology and coloration to L. quadrivittata (Peters, 1867; distribution: Mindanao [type locality] as well as Negros, Bohol, Palawan, Siquijor, Little Govenen, Cebu, Leyte, and Camiguin Islands in the southern Philippines). Lipinia quadrivittata has a light brown to yellow base color with dark, longitudinal dorsolateral stripes. In contrast, L. inexpectata has a dark brown base color with light longitudinal dorsolateral stripes (Fig. 1). In addition, L. inexpectata has a series of longitudinal dark spots lateral to the paravertebral stripe, which are lacking in L. quadrivittata. Additionally, in $L$. inexpectata, only supralabial IV contacts the orbit, as opposed to supralabials IV and V contacting the orbit in $L$. 
quadrivittata; and L. inexpectata is terrestrial (as opposed to arboreal). The two species show a high level of sequence divergence (15.4$16.0 \%)$, and character based genetic analysis demonstrates that $L$. inexpectata is distinct and a separate evolutionary lineage (Table 1 ). Because all specimens previously identified as $L$. quadrivittata from Borneo are referable to $L$. inexpectata (see Appendix 1), we confirm that there are no authentic records of L. quadrivittata for Borneo.

Lipinia inexpectata is here compared with all other known congeners, listing only opposing suite of characters: albodorsalis (Vogt, 1932) (distribution: Papua New Guinea), SVL to $54 \mathrm{~mm}$; external ear opening present; seven supralabials; supralabial five in midorbital position; 22-25 midbody scale rows; $19-23$ lamellae under toe IV; and dorsum pale yellow with a dark upper lateral stripe; auriculata (Taylor, 1917) (distribution: Philippines: Negros and Masbate Islands), external ear opening present; 22-25 midbody scale rows; and 55-61 longitudinal scale rows between parietals and tail base; cheesmanae (Parker, 1940) (distribution: Indonesia: Papua Province; New Guinea), 28 midbody scale rows; five pairs of nuchals; and dorsum coppery with a middorsal row of dark spots forming an interrupted zigzag line from the occiput to tail base, and a dark lateral band along the flanks and tail, with a series of large, semicircular spots along its upper border; infralineolata (Günther, 1873; distribution: Indonesia: Sulawesi and Sangihi Islands), SVL to $49 \mathrm{~mm}$; 22 midbody scale rows; 18-25 lamellae under toe IV; and lips and limbs with brown spots; leptosoma (Brown and Fehlmann, 1958) (distribution: Palau Islands, at present, the Republic of Belau), external ear opening present; 22-26 midbody scale rows; supralabial five in midorbital position; 7-10 lamellae under toe $\mathrm{IV}$; and arboreal habits; longiceps (Boulenger, 1895) (distribution: New Guinea, Fergusson, Misima, and Trobriand Islands), SVL $43 \mathrm{~mm}$; external ear opening present; 24 midbody scale rows; 19 lamellae under toe IV; rectilinear black dorsolateral lines converge at tail base; and tail golden yellow; macrotympanum (Stoliczka, 1873) (distribution: India: Andaman and Nicobar Archipelago), 21-23 midbody scale rows; seven supralabials; and coloration of dorsum contrasting black and yellow and tail bright red in life (color photograph in Das, 2002); miangensis (Werner, 1910) (distribution: Indonesia: Pulau Miang, Kalimantan Timur; Borneo), external ear opening present; two vertebral series of scales enlarged; 24 midbody scale rows; 62 ventral scales; 21 lamellae on toe IV; dorsal surface golden with two dark brown longitudinal stripes from the snout-tip, over the eyes, to around the middle of tail; a dark line from eye to base of fore limb; and venter unpatterned greenish-white; miotis (Boulenger, 1895; distribution: New Guinea), SVL to $52 \mathrm{~mm}$; external ear opening present; supralabial $\mathrm{V}$ in midorbital position; midbody scale rows 24-26; and dorsum golden brown with small dark spots in two longitudinal series; nitens (Peters, 1871) (distribution: Malaysia: western Sarawak; Borneo), a small member of the genus, SVL to $33.6 \mathrm{~mm}$; two enlarged paravertebral scale rows; external ear opening replaced by a scaly dimple; subcaudal scales enlarged; dorsal surface metallic green; sides of body spotted with black and green; and pale yellow vertebral stripe, with jagged edged black lines, one on each side from supraorbital to tail base; noctua (Lesson, 1826) (distribution: Indonesia: Maluku and Papua Province; also, Papua New Guinea, the Admiralty and Bismarck Archipelago, as well as the Solomon Islands), SVL to $47 \mathrm{~mm}$; $24-28$ midbody scale rows; seven supralabials, fifth in midorbital position; and head with a light spot; nototaenia Boulenger, 1914 (distribution: Indonesia: West Papua [New Guinea]), SVL to $47.5 \mathrm{~mm}$; external ear opening present; $24-25$ midbody scale rows; 52-55 longitudinal scale rows between parietals and base of tail; seven supralabials; occidentalis Günther, 2000 (distribution: Indonesia: Papua Province; New Guinea), external ear opening present; 24-26 midbody scale rows; 20-21 lamellae under toe IV; broad brownish dorsal band terminates at tailbase, where it forms a dark tip; and pale dorsal stripes absent; pulchella Gray, 1845 (distribution: the Philippines), external ear opening present; 51-58 longitudinal scales between parietals and tail base; 22-26 midbody scale rows; and 24-31 lamellae under toe IV; pulchra Boulenger, 1903 (distribution: New Guinea), external ear opening present; 24 midbody scale rows; 22 lamellae under toe IV; supralabial five in subocular position; and dorsum black with five greenishwhite longitudinal lines; rabori (Brown and Alcala, 1956) (distribution: Philippines: Negros Island), a large member of the genus, SVL to $51.0 \mathrm{~mm}$ in males and $54.8 \mathrm{~mm}$ in females; external ear opening present; 7-8 supralabials; seven infralabials; 22 midbody scale rows; $52-57$ longitudinal scale rows between parietals and tail base; 18-21 lamellae under toe IV; relicta (Vinciguerra, 1892) (distribution: Indonesia: Mentawai Archipelago off Sumatra), SVL to $56 \mathrm{~mm}$; 18 lamellae under toe IV; tail thick; a light vertebral stripe present and labials with a small white spot; rouxi (Hediger, 1934) (distribution: New Ireland, northeast Papua New Guinea and Bismarck Archipelago), 2228 midbody scale rows; $8-9$ supraciliaries; $22-26$ lamellae under toe IV; left oviduct missing; 
venter greenish-white in life (fide Greer and Mys, 1987) and arboreal habits; semperi (Peters, 1867) (distribution: Philippines: Mindanao and Camiguin Islands), SVL 43.9-49.9 mm; external ear opening present; 22-24 midbody scale rows; seven supralabials; 53-58 longitudinal scale rows between parietals and tail base; and 1921 lamellae under toe IV; septentrionalis Günther, 2000 (distribution: Indonesia: Papua Province; New Guinea), 24-26 midbody scale rows; seven supralabials; $18-22$ lamellae under toe IV; and a cream vertebral stripe that broadens towards the tail, bordered by a dark line on each side; subvittata (Günther, 1873) (distribution: Indonesia: Sulawesi and Java; Philippines: Mindanao Island), SVL 47-56 mm; dorsal longitudinal stripes extend to the forearm region; 57-64 longitudinal scale rows between parietal and tail base; and 22 midbody scale rows; surda (Boulenger, 1900) (distribution: Peninsular Malaysia); supralabial IV and V contact orbit of eye; preanals subequal to ventral scales; and dorsum uniform brown; venemai (Brongersma, 1953; distribution: Indonesia: Papua Province; New Guinea), SVL 54.0-57.5 mm; external ear opening present; $2-3$ pairs of nuchals; seven supralabials; 24 or 26 midbody scale rows; 59-60 longitudinal scale rows between parietals and base of tail; 19-21 lamellae under toe IV; and dorsum deep olive gray, the supraciliary region whitish, broadening posteriorly; vittigera (Boulenger, 1894; distribution: Peninsular Malaysia, Sumatra and Borneo), external ear opening present; 25 lamellae on toe IV; 28 midbody scale rows; and dorsal pattern comprising dark gray and bright yellow stripes (color photograph in Cox et al., 1998); vulcania Girard, 1856 (distribution: Philippines: Mindanao and Luzon islands), external ear opening present; seven supralabials; supralabial V in midorbital position; 32 midbody scale rows; 62 longitudinal scale rows between parietals and tail base; and 17 lamellae under toe IV; and zamboangensis (Brown and Alcala, 1963) (distribution: Philippines: Mindanao Island), SVL to $44.5 \mathrm{~mm}$; external ear opening present; 24 midbody scale rows; 54 longitudinal scale rows between parietals and tail base; 20 lamellae under toe IV; and dorsum greenish with brown iridescence.

Acknowledgments.-We thank Sabah Parks for permission, and our respective institutions, the Institute of Biodiversity and Environmental Conservation, Universiti Malaysia Sarawak and Louisiana State University, for supporting our research on the herpetology of Borneo. This research was funded in part by National Science Foundation grants DEB 0445213 and DBI 0400797 to CCA as well as by a Louisiana State University Faculty Research grant. Curators of the following institutions permitted us to examine comparative material under their care: E. N. Arnold and C. J. McCarthy (BMNH), A. E. Leviton and J. Vindum (CAS), R. F. Inger, A. Resetar, and H. Voris (FMNH), J. E. Cadle, J. Hanken, the late E. E. Williams and J. Rosado (MCZ), E. Yen and M. Naming (SBC), C. Leh (SM), M. Mohammed, and L. Kimsui (UMS), R. I. Crombie, W. R. Heyer, and G. R. Zug (USNM), K. K. P. Lim and P. K. L. Ng (ZRC), and J. R. Alfred, S. K. Chanda, and N. C. Gayen (ZSI). We thank R. M. Brown (University of Kansas) for Philippine tissues and K. K. P. Lim and J. Boundy for line drawings. Finally, we are grateful for comments on the manuscript by $\mathrm{L}$. Grismer and two anonymous reviewers.

\section{Literature Cited}

Alcala, A. C. 1986. Guide to Philippines Flora and Fauna. Volume X. Amphibians and Reptiles. Natural Resources Management Center, Ministry of Natural Resources and University of the Philippines, Manila, Philippines.

Austin, C. C. 1995. Molecular and morphological evolution in South Pacific scincid lizards: morphological conservatism and phylogenetic relationships of Papuan Lipinia (Scincidae). Herpetologica 51:291-300.

1998. Phylogenetic relationships of Lipinia (Scincidae) from New Guinea based on DNA sequence variation from the mitochondrial $12 S$ rRNA and nuclear $c$-mos genes. Hamadryad 23:93-102.

1999. Lizards took express train to Polynesia. Nature 397:113-114.

Austin, C. C., And G. R. Zug. 1999. Molecular and morphological evolution in the south-central $\mathrm{Pa}$ cific Skink Emoia tongana (Reptilia: Squamata): uniformity and human-mediated dispersal. Australian Journal of Zoology 47:425-437.

Bauer, A. M., R. Günther, and M. Klipfel. 1995. Introduction, annotated bibliography and synopsis of taxa. In The Herpetological Contributions of Wilhelm C. H. Peters (1815-1883), pp. 5-87. Society for the Study of Amphibians and Reptiles, Ithaca, NY.

Boulenger, G. A. 1887. Catalogue of Lizards in the British Museum (Natural History). 2nd ed. Vol. III. Lacertidae, Gerrhosauridae, Scincidae, Anelytropidae, Dibamidae, Chamaeleontidae. British Museum (Natural History), London.

_ - 1894. A list of reptiles and batrachians collected by Dr. E. Modigliani on Sereinu (Sipora), Mentawei Islands. Annali del Museo Civico di Storia Naturale di Genova, Series 2 14:614-618.

__. 1912. A Vertebrate Fauna of the Malay Peninsula from the Isthmus of Kra to Singapore, including the Adjacent Islands. Reptilia and Batrachia. Taylor and Francis, London.

Brown, W. C., AND A. C. Alcala. 1956. A review of the Philippine lizards of the genus Lygosoma (Leiolopisma). Occasional Papers of the Natural History Museum of Stanford University 3:1-10. 
1980. Philippine lizards of the family Scincidae. (with a description of a new species of Tropidophorus by James P. Bacon) Silliman University. Natural Science Monograph Series 2. Silliman University Press, Dumaguete, Philippines.

Brown, W. C., AND A. Fehlmann. 1958. A new genus and species of arboreal scincid lizards from the Palau Islands. Occasional Papers of the Natural History Museum of Stanford University 6:1-7.

Cox, M. J., P. P. Van Dijk, J. Nabhitabhata, and K. ThIRAKHUPT. 1998. A Photographic Guide to Snakes and Other Reptiles of Peninsular Malaysia, Singapore and Thailand. New Holland Publishers (UK) Ltd., London.

DAS, I. 1997. Rediscovery of Lipinia macrotympanum (Stoliczka, 1873) from the Nicobars Islands, India. Asiatic Herpetological Research 7:23-26.

2002. A Photographic Guide to the Snakes and Other Reptiles of India. New Holland Publishers (U.K.) Ltd., London.

- 2004. A Pocket Guide. Lizards of Borneo. Natural History Publications (Borneo) Sendirian Berhad, Kota Kinabalu, Malaysia.

DAs, I., AND A. E. GReER. 2002. Lipinia nitens (Peters, 1871): discovery of a second specimen and a redescription of the holotype. Raffles Bulletin of Zoology 50:483-485.

Denzer, W., and U. Manthey. 1991. A nominal checklist of the lizards inhabiting Peninsular Malaysia and Singapore. Raffles Bulletin of Zoology 39:309-322.

De RoorJ, N. 1915. The Reptiles of the Indo-Australian Archipelago. Vol. I. Lacertilia, Chelonia, Emydosauria. E. J. Brill, Leiden, The Netherlands.

Edwards, A. W. F. 1972. Likelihood. Cambridge University Press, Cambridge.

Felsenstein, J. 1981. Evolutionary trees from DNA sequences: a maximum likelihood approach. Journal of Molecular Evolution 17:368-376.

- 1985. Confidence limits on phylogenies: an approach using the bootstrap. Evolution 39: 783-791.

Gonzalez, P., P. Francisco, M. Nogales, J. JimenezAsensio, M. Hernandez, and V. M. Cabrera. 1996. Phylogenetic relationships of the Canary Islands endemic lizard genus Gallotia (Sauria: Lacertidae), inferred from mitochondrial DNA sequences. Molecular Phylogenetics and Evolution 6:63-71.

Graybeal, A. 1994. Evaluating the phylogenetic utility of genes: a search for genes informative about deep divergences among vertebrates. Systematic Biology 43:174-193.

GrEer, A. E. 1974. The generic relationships of the scincid lizard genus Leiolopisma and its relatives. Australian Journal of Zoology (Supplement Series) 31:1-67.

Greer, A. E., AND B. Mrs. 1987. Resurrection of Lipinia rouxi (Hediger, 1934) (Reptilia: Lacertilia: Scincidae), another skink to have lost the left oviduct. Amphibia-Reptilia 8:417-418.

GÜNTHER, R. 2000. In alten Sammlungen aus Neuguinea entdeckt: Zwei neue Arten der Gattung Lipinia (Squamata: Scincidae). Salamandra 36:157-174.

Hikida, T., AND H. Ota. 2005. Book Review. Lizards of Borneo (by Indraneil Das, 2004). Current Herpetology 24:43-47.
Hillis, D. M., AND J. J. Bull. 1993. An empirical test of bootstrapping as a method for assessing confidence in phylogenetic analysis. Systematic Biology 42:182-192.

Hillis, D. M., A. Larson, S. K. Davis, and E. A. Zimmer. 1990. Nucleic acids. III. Sequencing. In D. M. Hillis and C. Moritz (eds.), Molecular Systematics, pp. 318-372. Sinauer Associates, Sunderland, MA.

INGER, R. F. 1980. Relative abundances of frogs and lizards in forests of Southeast Asia. Biotropica 12:14-22.

IsKANDAR, D. T. 2004. The Amphibians and Reptiles of Malinau Region, Bulungan Research Forest, East Kalimantan. Annotated Checklist with Notes on Ecological Preferences of the Species and Local Utilization. Center for International Forestry Research, Bogor and Institut Teknologi Bandung, Bandung, Indonesia.

Kocher, T. D., W. K. Thomas, A. Meyer, S. V. Edwards, S. PaAbo, F. X. Villablanca, and A. C. WILSON. 1989. Dynamics of mitochondrial DNA evolution in animals; amplification and sequencing with conserved primers. Proceedings of the National Academy of Sciences, USA 86:61966200 .

Leviton, A. E., S. C. Anderson, R. H. Gibbs, E. Heal, and C. E. Dawson. 1985. Standards in herpetology and ichthyology. Part I. Standard symbolic codes for institutional resource collections in herpetology and ichthyology. Copeia 1985: 802-832.

Leviton, A. E., S. C. Anderson, and R. H. Gibbs. 1988. Standards in herpetology and ichthyology. Part I. Standard symbolic codes for institutional resource collections in herpetology and ichthyology. Supplement 1. Additions and corrections. Copeia 1988:280-282.

Lloyd, M., R. F. Inger, And F. W. King. 1968. On the diversity of reptile and amphibian species in a Bornean rain forest. American Naturalist 202: 497-515.

Manthey, U., and W. Grossmann. 1997. Amphibien \& Reptilien Südostasiens. Natur und Tier Verlag, Münster, Germany.

Mittleman, M. B. 1952. A generic synopsis of the lizards of the subfamily Lygosominae. Smithsonian Miscellaneous Collection 117:1-35.

Ota, H., T. Hikida, J. Nabhitabhata, and S. Panha. 2001. Cryptic taxonomic diversity in two broadly distributed lizards of Thailand (Mabuya macularia and Dixonius siamensis) as revealed by chromosomal investigations (Reptilia: Lacertilia). Natural History Journal of Chulalongkorn University 1: $1-7$.

Posada, D., and K. A. Crandall. 1998. Modeltest: testing the model of DNA substitution. Bioinformatics 14:817-818.

Repin, R., And D. Sundaling. 2000. Checklist of trees along the trails on the islands of Tunku Abdul Rahman Park, Sabah, Malaysia. Sabah Parks Nature Journal 3:79-105.

SheA, G. M., AND A. E. Greer. 2002. From Sphenomorphus to Lipinia: generic reassignment of two poorly known New Guinean skinks. Journal of Herpetology 36:148-156. 
Smedley, N. 1928. Some reptiles and Amphibia from the Anamba Islands. Malayan Branch of the Royal Asiatic Society 6:76-77.

Smith, M. A. 1930. The Reptilia and Amphibia of the Malay Peninsula from the Isthmus of Kra to Singapore including the adjacent islands. Bulletin of the Raffles Museum 3: (2)+ xviii + $1-149$.

Storr, G. M., L. A. Smith, and R. E. Johnstone. 1999. Lizards of Western Australia. I. Skinks. Rev. 2nd ed. Western Australian Museum, Perth, Western Australia, Australia.

SwOFFORD, D. 1999. PAUP* Phylogenetic Analysis Using Parsimony and Other Methods). Version 4.0.0. Sinauer Associates, Sunderland, MA.

TAN, F.-L. 1993. Checklist of Lizards of Sabah. Sabah Parks Trustees, Kota Kinabalu, Malaysia.

TAYLOR, E. H. 1935. A taxonomic study of the cosmopolitan scincoid lizards of the genus Eumeces with an account of the distribution and relationships of its species. Kansas University Science Bulletin 23:1-643.

- 1963. The lizards of Thailand. University of Kansas Science Bulletin 44:687-1077.

Thompson, J. D., D. G. Higgins, And T. J. Gibson. 1997. CLUSTALW: improving the sensitivity of progressive multiple sequence alignment through sequence weighting, positions-specific gap penalties and weight matrix choice. Nucleic Acids Research 22:4673-4680.

THORPE, R. S. 1996. The use of DNA divergence to help determine the correlates of evolution of morphological characters. Evolution 50:524-531.

Thorpe, R. S., AND A. Malhotra. 1998. Molecular and Morphological Evolution within Small Islands. Oxford University Press, Oxford

Thorpe, R. S., D. P. McGregor, A. M. Cumming, And W. C. JORDAN. 1994. DNA evolution and colonization sequence of island lizards in relation to geological history: mtDNA RFLP, cytochrome $b$, cytochrome oxidase, 12s rRNA sequence, and nuclear RFLP analysis. Evolution 48:230-240.

Toda, M., T. Hikida, and H. OtA. 2000. Discovery of sympatric cryptic species within Gekko hokouensis (Gekkonidae: Squamata) from the Okinawa Islands, Japan, by use of allozyme data. Zoologica Scripta 30:1-11.

Voris, H. K. 2000. Maps of Pleistocene sea levels in Southeast Asia: shorelines, river systems and time durations. Journal of Biogeography 27: 1153-1167.

WAKELEY, J. 1994. Substitution rate variation among sites and the estimation of transition bias. Molecular Biology and Evolution 11:436-442.

1996. The excess of transitions among nucleotide substitutions-new methods of estimating transition bias underscore its significance. Trends in Ecology and Evolution 11:158-163.

Welch, K. R. G., P. S. CoOKe, And A. S. Wright. 1990. Lizards of the Orient: A Checklist. Robert E. Krieger Publishing Company, Malabar, FL.

ZUG, G. R. 1991. Lizards of Fiji: natural history and systematics. Bishop Museum Bulletin in Zoology 2:i-xii, 1-136.

Accepted: 20 September 2006.

\section{ApPENDIX 1}

List of Comparative and Additional Material Examined

Lipinia inexpectata Das and Austin, 2007: MALAYSIA: Nanga Tekalit Camp on Sungei Mengiong, Kapit Division, Sarawak (FMNH 138539; 152400); Sandakan, Sandakan District, Sabah (BMNH 95.9.11.16); Sepagaya Forest Reserve, Sandakan District, Sabah (FMNH 63678); Sepilok, Sandakan District, Sabah (USNM 306415); Danum Valley, Lahad Datu District, Sabah (FMNH 230189; UMS 04399-04400); southeastern end of Dewhurst Bay, Kinabatangan District (FMNH 63678); KALIMANTAN: Pulau Nunukan, Kalimantan Timur Province (FMNH 72448).

Lipinia longiceps (Boulenger, 1895): PAPUA NEW GUINEA: Aitape (MCZ R-48587).

Lipinia macrotympanum (Stoliczka, 1873): INDIA: Pulo Ulan (= Tiden), Little Nicobar Island, Andaman and Nicobar Islands (cited by Das, 1997; MCZ R-176760), Andaman Island, Andaman and Nicobar Islands (ZSI 5571, holotype of Mocoa macrotympanum Stoliczka, 1873).

Lipinia nitens (Peters, 1871): MALAYSIA: base of Gunung Pueh, Kuching Division, Sarawak (cited by Das and Greer, 2002; ZRC 2.4861); base of Gunung Matang, Kuching Division (illustrated in Das, 2004:61; ZRC 2.5746).

Lipinia noctua (Lesson, 1826): FIJI: Tubutkii (MCZ R15013).

Lipinia pulchella Gray, 1845: PHILIPPINES: Zamboanga, Mindanao (MCZ R-26440).

Lipinia quadrivittata (Peters, 1867): INDONESIA: Salopa Waterfall, northwest of Poso, Sulawesi (ZRC 2.4652); PHILIPPINES: Sant Cotobato, Mindanao (CAS 61960-61).

Lipinia rabori (Brown and Alcala, 1956): PHILIPPINES: Maite River, Cuernos Negros Oriente (MCZ R-54393).

Lipinia semperi (Peters, 1867): PHILIPPINES: Agusan del Norte (MCZ R-20120).

Lipinia vittigera (Boulenger, 1894): MALAYSIA: Bukit Meraja, Bau, Kuching Division, Sarawak (SBC R.1); Kota Samarahan, Sarawak (FMNH 147561; 149371-74); Pulau Talang Talang Besar, Kuching Division (SM uncat. [two specimens]); Baram District, Miri Division, Sarawak (cited by de Rooij, 1915:232; BMNH 97.3.4.2); Danum Valley Field Centre, Lahad Datu District, Sabah (FMNH 241315-16; 241316; 246356-57); Jor Batang, Padang, Perak (ZRC 2.1637); Salang, Pulau Tioman, Pahang Samarahan Division, Sarawak (ZRC 2.4677); Labang Camp on Sungei Seran, Kapit Division, (ZRC 2.5151); The Gap Resthouse, Fraser's Hill, Selangor (ZRC 2.4622); SINGAPORE: Nee Soon (ZRC 2.4575); VIETNAM: Bau Sau, Nam Cat Tien, Dong Nai Province (ZRC 2.5474-78).

\section{ApPENDIX 2}

Two hundred ninety-three base-pair DNA sequences from the mitochondrial $c y t b$ gene for Lipinia inexpectata (from the type series), Lipinia quadrivittata (topotype material from Mindanao; CCA 1268-70), and three other congeneric species (Lipinia noctua (SAMA R47838) from Papua New Guinea, Lipinia leptosoma (SAMA R47903 and R47904) from Palau, and Lipinia pulchella (TNHC 53979) from the Philippines, and the outgroup Sphenomorphus leptofasciatus (SAMA R4195) from New Guinea. A dot indicated the same base as found in the top reference outgroup sequence SAMA R4195. 
SAMA R4195 TNHC 51595

CCA1269

CCA 1268

CCA 1270

ZRC ID7190

ZRC ID7191

SAMA R47903

SAMA R47904

TNHC 53979

SAMA R4195

TNHC 51595

CCA1269

CCA 1268

CCA 1270

ZRC ID7190

ZRC ID7191

SAMA R47903

SAMA R47904

TNHC 53979

SAMA R4195

TNHC 51595

CCA1269

CCA 1268

CCA 1270

ZRC ID7190

ZRC ID7191

SAMA R47903

SAMA R47904

TNHC 53979

SAMA R4195

TNHC 51595

CCA1269

CCA 1268

CCA 1270

ZRC ID7190

ZRC ID7191

SAMA R47903

SAMA R47904

TNHC 53979

SAMA R4195

TNHC 51595

CCA1269

CCA 1268

CCA 1270

ZRC ID7190

ZRC ID7191

SAMA R47903

SAMA R47904

TNHC 53979

SAMA R4195

TNHC 51595

CCA1269

CCA 1268

CCA 1270

ZRC ID7190

ZRC ID7191

SAMA R47903

SAMA R47904

TNHC 53979
TCTCTTCTAGGCCTCTGCCTAATCGCACAGGTACTCACAGGATTATTCCT ..................T.T......GCA..C..CC.T....

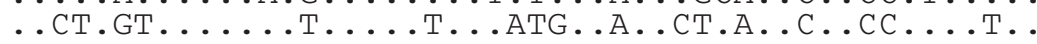

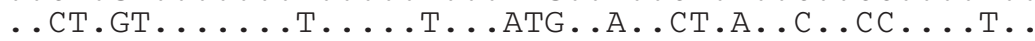

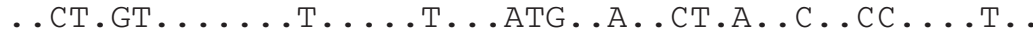
.CT.G. C...T.........A.A. . .A. . A. CC ....

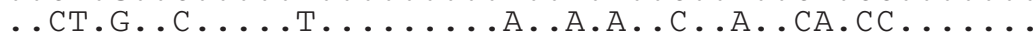
..... ......... . ......А.T.C..C.G... . С...T....... . ........ . . . С .G... . С...С.А.А.....ТАТ..А..Т.А........ TGCAATACATTACACAGCAGACATCTCCTCAGCCTTTTCATCCGTCGCCC G..C..G...........T.........AA.T... $\ldots \ldots \ldots$........................... $\ldots \ldots \ldots$..................... . . . $\ldots \ldots \ldots$. . . . . . . . . . . . . . С............

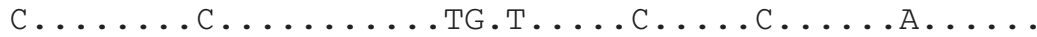
G.............................. G................................ А.С............. . . ...А.А. . ATATCTGCCGCGACGTTCAACACGGTTGACTAATCCGAAACCTACATGCC . С..... . . . . . . . . . . . . . . . . Т $\ldots \ldots \ldots$. . . . . . . . . . . . . . . $\ldots \ldots \ldots$..................... $\ldots \ldots \ldots$. . . . . . . . . . . . . . . .

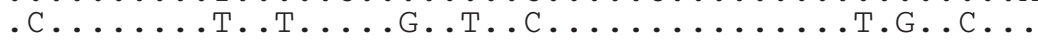

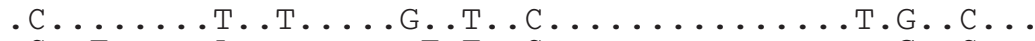
. С. .......... Т. . С............. . С. .......... Т. ................

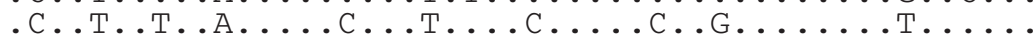
AACGGCGCCTCTATATTCTTTATTTGCCTTTACCTACACGTCGGACGGGG ........ . . .... . . ......TA........... $\ldots \ldots$.................. ............. $\ldots \ldots$.............................. $\ldots \ldots G \ldots \ldots G \ldots \ldots$...................... $\ldots$. . ......G.T.......G...T......... $\ldots$........G.T.................... $\ldots$. ................. T... .TA...... . $\ldots$........... . . . . . .. . .А..... . .............. . . . ....TA...... ACTTTATTATGGCTCCTACATATACAAAGAGACATGAAATATCGGCGTTG

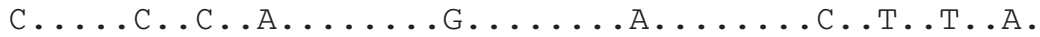
C.G.C.C...G...G.TT...A....... . . .AA C..G.C.....G...G.TT.............T.AA

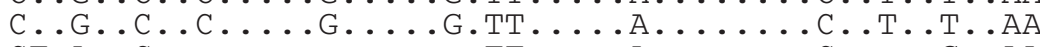
CT.A. . . ........ . . . ..........AA CT.A.С.........TT...............AA .T.A.C.C . . . . . T. . . . . . . . . . . .T.A.C.C........G.....A.........G.C.

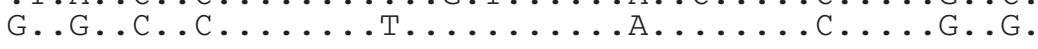
TCCTTCTACTACTTGTAATAGCAACCGCCTTTGTAGGCTACGT .G..G..T............T..A........T. ... СТ.Т....................... $\ldots$. СT. . . . . ................... ‥ СT. . . . . . . . . . . . . . . . C.T.GT.C....C.................. C.T.GT.C.C.C........G.G..C........ ...AT.C............... . . . ......

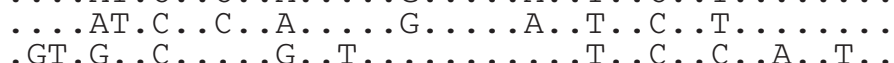

